\title{
Nitric Oxide as a Signal in Inducing Secondary Metabolites During Plant Stress
}

\author{
Parankusam Santisree, Hemalatha Sanivarapu, \\ Sriramya Gundavarapu, Kiran K. Sharma, and \\ Pooja Bhatnagar-Mathur
}

\section{Contents}

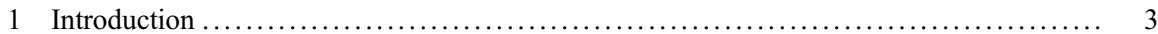

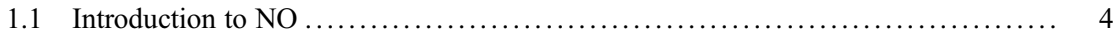

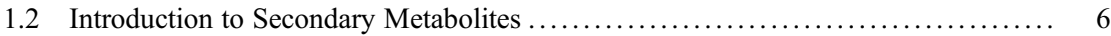

2 Production of Secondary Metabolites in Plants Under Abiotic Stress . . . . . . . . . . . . . . 7

2.1 Influence of Temperature Stress on Secondary Metabolites ..................... 9

2.2 Influence of Salt on Secondary Metabolites ............................... 9

2.3 Influence of Drought on Secondary Metabolites ........................... 10

2.4 Influence of Light on Secondary Metabolites .............................. 11

2.5 Influence of Heavy Metal on Secondary Metabolites ......................... 11

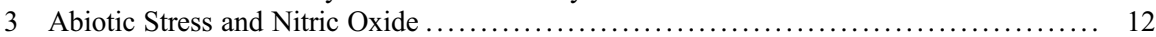

4 Role of NO in Inducing Secondary Metabolites ............................... 16

4.1 NO-Mediated Elicitation of Secondary Metabolites Under Abiotic Stress ......... 18

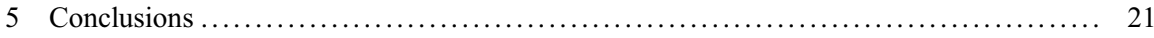

References $\ldots \ldots \ldots \ldots \ldots \ldots \ldots \ldots \ldots \ldots \ldots \ldots \ldots \ldots \ldots \ldots \ldots \ldots \ldots \ldots \ldots \ldots \ldots \ldots \ldots \ldots \ldots \ldots \ldots \ldots \ldots \ldots \ldots, 21$

\begin{abstract}
Secondary metabolites are the major defense elements of plants against biotic and abiotic stress conditions. They are diverse and valuable natural products induced by a variety of environmental and developmental cues. In recent years, NO has been successfully used as elicitor to stimulate secondary metabolite accumulation in plants. Emerging evidence has established the significant role of NO in plant growth and defense responses in plants. Several abiotic and biotic stress factors can induce NO-mediated regulation of the biosynthetic pathways of metabolites that can consequently alter their biological reaction toward the given stress. Moreover, exogenous treatments with NO donors also enhanced the

P. Santisree $(\bowtie) \cdot$ H. Sanivarapu $\cdot$ S. Gundavarapu $\cdot$ K. K. Sharma $\cdot$ P. Bhatnagar-Mathur Research Program on Grain Legumes, International Crops Research Institute for the Semi-Arid Tropics (ICRISAT), Patancheru, Hyderabad, Telangana, India e-mail: s.parankusam@cgiar.org; santhikinnu@gmail.com; hemalatha.icrisat@gmail.com; sriramya.gundavarapu@gmail.com; kksarmai@gmail.com; poojavaibhav@gmail.com
\end{abstract}


accumulation of secondary metabolites including phenolics, flavonoids, and caffeic acid derivatives in several species suggesting the importance of NO accumulation for the secondary metabolic production. Complete elucidation of its role in the production of such secondary metabolites which are pharmaceutically significant is very essential for improving the large-scale commercial production and enhancing stress resilience in plants. Although several reports suggested the induction of secondary metabolites and NO against a range of stress factors, to establish link between NO and secondary metabolites under stress needs a deeper investigation. This compilation chiefly summarize NO biosynthesis, signaling, and functions under abiotic stress in plants highlighting what is currently known about secondary metabolite induction by NO in plants.

\title{
Keywords
}

Nitric oxide $\cdot$ Secondary metabolites $\cdot$ Abiotic stress $\cdot$ Biotic stress $\cdot$ Phenolics Flavonoids

\author{
List of Abbreviations \\ ABA Abscisic acid \\ AP2/ERF APETALA2/ethylene response factor \\ APX Ascorbate peroxidase \\ AsA-GSH Ascorbic acid-glutathione \\ cADPR Cyclic ADP-ribose \\ CAT Catalase \\ Cd Cadmium \\ cGMP Cyclic guanosine monophosphate \\ c-PTIO 2-(4-Carboxyphenyl)-4,4,5,5-tetramethylimidazoline-1-oxyl-3- \\ oxid \\ $\mathrm{Cu} \quad$ Copper \\ DAF-2DA 4,5-Diaminofluorescein diacetate \\ eNOS Endothelial NOS \\ GABA $\quad \gamma$-Aminobutyric acid \\ $\mathrm{H}_{2} \mathrm{O}_{2} \quad$ Hydrogen peroxide \\ iNOS Inducible NOS \\ L-NAME L-N ${ }^{\mathrm{G}}$-Nitroarginine methyl ester; $N(\mathrm{G})$-Nitro-L-arginine methyl \\ ester \\ MDA Malondialdehyde \\ MeJA Methyl jasmonate \\ MYB Myb-related protein B \\ $\mathrm{NaCl} \quad$ Sodium chloride \\ NADPH Nicotinamide adenine dinucleotide phosphate \\ nNOS Neuronal NOS \\ $\mathrm{NO} \quad$ Nitric oxide \\ $\mathrm{NO}_{2} \quad$ Nitrogen dioxide \\ NOS Nitric oxide synthase \\ NR Nitrite reductase
}




$\begin{array}{ll}\mathrm{O}_{3} & \text { Ozone } \\ \mathrm{PAL} & \text { Phenylalanine ammonia-lyase } \\ \mathrm{Pb} & \text { Lead } \\ \mathrm{PCD} & \text { Programmed cell death } \\ \mathrm{POD} & \text { Peroxidase } \\ \text { PSII } & \text { Photosystem II } \\ \text { PTMs } & \text { Posttranslational protein modifications } \\ \text { ROS } & \text { Reactive oxygen species } \\ \mathrm{SNP} & \text { Sodium nitroprusside } \\ \mathrm{SOD} & \text { Superoxide dismutase } \\ \text { ZN } & \text { Zinc }\end{array}$

\section{Introduction}

Abiotic stress is defined as the harmful impact that nonliving factors including environment factors exert on the living systems such as plants and animals growing in the specific vicinity. Both plants and animals have evolved distinct mechanisms to survive abiotic stress imposed due to extreme climate. Plant survival is often challenged by a variety of different abiotic stress factors including drought, temperature extremes, heavy metals and salinity in soil, wounding, ozone, and UV-B stress. Water deficit and high temperatures are perhaps the two major abiotic stresses which are detrimental to crop growth and yield worldwide $[1,2]$. Salts and heavy metal accumulation in soil is also prevailing in crop lands. Furthermore, recent years have seen the raising surface $\mathrm{O}_{3}$ levels due to urbanization and industrial revolution which has also become toxic both for human health and vegetation [3]. On the other hand, the damage of the stratosphere ozone layer in turn causes an increase in UV-B exposure that leads to an increase of ion leakage, membrane protein oxidation, loss of photosynthetic efficiency, and ultimately global yield loss. Longer and severe stress episodes result in production of redox active molecules that in turn result in oxidation of proteins, lipids, and nucleic acids [4].

Given the sessile nature, plants have developed more complex mechanisms to sense and respond against the given stress condition. Plants respond to stress by activating tolerance mechanisms by perception and transmission of stress signals followed by a series of responses at multiple levels like morphological, physiological, biochemical, molecular, and anatomical adjustments [4]. These metabolic adjustments ultimately decide the stress tolerance or stress susceptibility of the plants. Although each stress induce a distinct defense response in plants, it is essential to understand the complete mechanism of plant defense to individual as well as stress in combination. Indeed in natural environments, plants may also be subjected to multiple stress responses at a time. Abiotic stresses disrupt the cellular redox homeostasis which leads to the oxidative stress or the generation of reactive oxygen species (ROS) [1]. Different plant groups may respond differently to the given stress dependent on the species, tolerance level, developmental stage, and tissue affected by the stress. This may be due to the variance in metabolic 
adjustments to stress that are different in different tissues and genotypes of the same plant. The metabolic tuning of plants is usually triggered by number of defense molecules that enhance protection [5]. Although plant responses are unique to different extremes, they utilize the common components and signaling pathways to trigger defense. Recent research has revealed nitric oxide (NO) as one of the critical components in several plant acclimation responses to both biotic and abiotic stress conditions [2]. Literature demonstrated that various abiotic factors induce NO generation that lead to the activation of cellular processes for protection against oxidative stress and metabolic adjustments for survival.

\subsection{Introduction to NO}

NO is a lipophilic gaseous signaling molecule having versatile functions in both plants and animals. The first discovery in 1772 by Joseph Priestley described NO as an air-polluting "nitrous air" without any specific color and odor. After two centuries, Klepper observed NO emission by air purging of herbicide-treated Glycine max leaves followed by other observations on $\mathrm{NO}$ as a bacterial metabolic by-product [6]. A breakthrough study by Robert F. Furchgott, Louis J. Ignarro, and Ferid Murad turned up the signaling functions of NO in mammalian species and secured the Nobel Prize at Physiology in 1998. From that point, there were many parallel investigations on exploration of $\mathrm{NO}$ generation and NO signaling in both plants and animals. However, the investigations on NO in mammals were much rapid wherein the role of NO was well demonstrated in many physiological processes including muscle relaxation, neural communication, immune responses, and programmed cell death.

A bit later, NO has been accepted as multitasking molecule with innumerable functions even in plants. The lipophilic and diffusible nature of NO makes it perfectly suitable for several signaling processes in plants [7]. NO also plays an active role in modifying the activity of enzymes and some key signaling components via posttranslational protein modifications (PTMs). NO also plays a duel role as an antioxidant and as oxidant depending on the cellular concentration and plant species and many other factors. Endogenous NO levels have been reported to get triggered by abiotic stress conditions in diverse plant species. NO play a vital role in increasing plant adaptation to stressful conditions by modifying various physiological processes. There has been sufficient data suggesting NO as an endogenous signal that mediates plant responses to various abiotic stimuli. Nevertheless NO also acts as a critical messenger during stimulation of hypersensitivity response to pathogens.

\subsubsection{Functions of NO}

Albeit NO is recognized as a toxic gas for plant foliage by early discoveries, later it was treated as a powerful signaling molecule in plant defense during pathogen infestation. NO is actively involved in a plethora of plant development responses including stomatal movement, seed germination [8], and floral transition besides 
having a significant role as anti-stress compound against a plethora of abiotic and biotic stresses such as drought, salinity, temperature extremes, UV-B, and heavy metal toxicity. Several reviews delineated the functions of NO in most of environmental abiotic stresses [2]. Besides, pharmacological studies using various $\mathrm{NO}$ donors and scavengers also demonstrated the pivotal role of $\mathrm{NO}$ in increasing plant tolerance to abiotic cues $[2,9]$. Till date, it has been reported that exogenous application of $\mathrm{NO}$ donors could enhance stress tolerance in many species of plants including reed, sunflower, wheat, rice, bitter orange, tobacco, and Arabidopsis. NO is critical for stress tolerance by modulating osmolytes accumulation and metabolite reprogramming [10].

Besides, number of researchers reviewed the crucial role of NO in moderating various plant hormone-mediated development and stress responses [11]. The protective effect of $\mathrm{NO}$ in most reports has been attributed to its antioxidant role due to its ability to activate antioxidant enzymes [2]. There are several studies that support NO inducing stimulation of major antioxidant enzymes such as ascorbate peroxidase (APX), catalase (CAT), and superoxide dismutase (SOD) during stress conditions $[12,13]$. Despite the emerging knowledge about NO-mediated plant stress responses including decreasing reactive oxygen species (ROS) levels and protecting membranes from oxidative damage, osmolyte accumulation, and regulation of various hormone-mediated signaling events, its functional status has been far from clarity. Nonetheless, the diffusible nature, short life, and complex chemistry in living systems of $\mathrm{NO}$ pose a great challenge to $\mathrm{NO}$ researchers [13].

\subsubsection{Synthesis and Signaling of NO}

In mammalian systems, NO is synthesized through well-characterized forms of nitric oxide synthase (NOS), iNOS, nNOS, and eNOS. Although the pace of investigations was bit slower in plants, initially two plant enzymes, nitric oxide synthase (NOS) and nitrate reductase (NR) [10], have been attributed for plant NO biosynthesis. Plants can also produce NO as a by-product of metabolic pathways including nitrogen fixation and respiration.

Later four major sources for $\mathrm{NO}$ generation have been deciphered in plants: nitrate reductase (NR) pathway, NOS pathway [14], and other enzymatic and nonenzymatic pathways [15]. Oxidative NO synthesis from L-arginine through NOS activity has been reported across the kingdoms including prokaryotes, unicellular eukaryotes, invertebrates, and mammals. However, the identification of NOS sequences from higher plants having high homology to already known NOS encoding genes [16] in other taxa is still awaiting. During the past decade, the first plant NOS-like gene (AtNOS1) in higher plants is identified in Arabidopsis having homology to a snail NOS. Additionally, the chlorotic symptoms of Atnos 1 seedlings disappeared by exogenous NO. Furthermore, the overexpression of AtNOS1 enhanced NO synthesis in Escherichia coli while proved to possess NOS activity by converting L-arginine to L-citrulline using commercial kits. However, its orthologs from maize and rice failed to show NOS activity indicating its function more as a regulator of NO rather than the actual gene coding for synthesis. Although few other studies build pharmacological evidence for the existence of NOS like enzyme 
in various plant species, the purification of relevant protein is still underway [14]. Nonetheless, the identification of two genes in green algae Ostreococcus tauri and Ostreococcus lucimarinus share approximately $40 \%$ homology to animal NOS genes and also exhibit NOS-like activity [17]. NR-mediated NO synthesis is very common and known to involve in several physiological processes and plant defense against biotic and abiotic stress [16]. In several cases NO production in plant tissues occurs either through nonenzymatic light-mediated conversion of carotenoids or enzymatic catalysis through NADPH nitrate reductase. NR, in addition to its primary nitrate (NO_3) oxidoreductase activity, is capable of reducing $\mathrm{NO}_{2}$ to $\mathrm{NO}$ with low efficacy [18]. Additionally, $\mathrm{NO}$ can also be produced through reductive pathways by assimilatory nitrate reductase, or through the mitochondrial electron transport system, or from xanthine dehydrogenase/oxidase [15]. The reductive NO synthesis from $\mathrm{NO}_{2}$ can occur in cytoplasm, mitochondria, chloroplast, peroxisomes, and the apoplast of the plant cells [18]. Plant mitochondrial enzymes present in the matrix or the intermembrane space are also assumed to oxidize L-arginine to NO.

Undoubtedly, NO has the ability to modify the activity of enzymes and some key signaling components through posttranslational protein modifications including protein $S$-nitrosylation, carbonylation, and tyrosine nitration [2, 13]. While the NOmediated protein modifications have been identified for distinct regulatory proteins such as antioxidant enzymes, there was less information on general mechanism by which NO is being sensed across multiple plant processes [2]. However, a study in $A$. thaliana suggested a unifying $\mathrm{N}$-end rule pathway proteolysis mechanism involved in NO sensing in plants [2]. Sufficient data placed cGMP, cADPR, L-phenylalanine ammonia-lyase $(P A L)$, and $P R-1$ as effectors of NO levels in plants [13].

In the past decade, researchers deployed different methods to elucidate NOdependent processes including NOS/NR activity assays, NO-binding fluorescent dyes, and various pharmacologic approaches using NO donors including sodium nitroprusside (SNP) and $S$-nitroso- $N$-acetylpenicillamine and NO scavengers 2-(4Carboxyphenyl)-4,4,5,5-tetramethylimidazoline-1-oxyl-3-oxide (cPTIO), and quantification of effectors by radioimmunoassay or liquid chromatography tandem-mass spectrometry $[9,15,17,19]$. The recent use of targeted nanodonors and nanoshutters has enhanced the specificity while reducing the pleiotropic responses and artifacts encountered with pharmacological compounds $[12,16]$. Numerous genetic studies have used Arabidopsis mutants with altered nitric oxide levels such as noal, nialnia2, and noxl to confirm the importance of $\mathrm{NO}$ accumulation in response to various stimuli [17]. Furthermore, the $n N O S$ transgenic lines [20] also underlined the generation of $\mathrm{NO}$ as a vital response for increasing plant adaptation to stress [9].

\subsection{Introduction to Secondary Metabolites}

Plant secondary metabolites are the compounds that have vital role in plant interactions and defense. While our understanding on their role in fundamental plant 
growth and development is improving, diverse arrays of secondary metabolites have been identified in higher plants. Most of them are synthesized from primary metabolites including carbohydrates, lipids, and amino acids [21, 22]. Secondary metabolites significantly contribute to develop specific aroma, tastes, and colors in plants that are in turn responsible for plant interactions with environment and defense against pathogens. In economic point of view, they are the major sources for natural products, pharmaceuticals, food additives, and flavors. The accumulation of secondary metabolites can be influenced by various genetic and environmental factors $[23,24]$. Secondary metabolites including toxoids, polysaccharides, and flavones serve as key components for plant interaction with the biotic and abiotic cues in their vicinity. Indeed, these are the signals of plant communication during symbiosis, seed dispersal, and plant completion with other plants [25].

Secondary metabolites are not essential to life but essential for survival. Indeed the specific phytochemical profile of species can be used for systematic classification of species in chemotaxonomy. Majority of the plants have four chemically distinct metabolite groups such as terpenes, phenolics, nitrogen, and sulfur-containing secondary metabolites [25]. Terpenes constitute the largest group of secondary metabolites usually derived from acetyl-coA or glycolytic intermediates. Terpenes are structurally diverse group including monoterpenes, sesquiterpenes, diterpene, triterpenes, and polyterpenes that constitute toxins and feeding deterrents in plants. Carotenoids, insecticides like pyrethroid, and phytohormone abscisic acid are the most popular examples of terpenes in plants [26]. Phenols are aromatic compounds derived from the shikimic acid pathway, having a significant role in plant defense against various bacterial, fungal pests, and disease. Few examples of phenols which include lignin, flavonoids, isoflavonoids, and coumarin derivatives play effectively against a range of plant pathogens, protect cells from UV-B radiation and oxidative stress, and promote symbiotic associations. Phytoalexins, thionins, defensins, and glutathiones are the well-known sulfur-containing secondary metabolites [26-28]. They are useful in plant growth as source of reduced sulfur, in stress responses as volatiles defensive substances. The nitrogen-containing secondary metabolites including alkaloids and cyanogenic glucosides and nonproteins amino acids such as canavanine and azetidine- 2 carboxylic acid are biosynthesized from common amino acids. These metabolites are mostly toxic and offer defense against pathogenic microbes and herbivoral animals and insects.

\section{Production of Secondary Metabolites in Plants Under Abiotic Stress}

Plants have potential to adopt some strategies to neutralize the effects of various abiotic stresses. External stress factors such as high and low temperature, salinity, alkalinity, UV, heavy metals, and drought can significantly affect the synthesis of secondary metabolites profiles (Table 1; [27]). The released secondary metabolites 
Table 1 Representative studies on the effect of abiotic stresses on synthesis of secondary metabolites in plants

\begin{tabular}{|c|c|c|c|}
\hline Stress & Plant species & Target metabolites & References \\
\hline Salt & $\begin{array}{l}\text { Carthamus tinctorius L., } \\
\text { Lycopersicon esculentum, } \\
\text { Oryza sativa L., Solanum } \\
\text { lycopersicum }\end{array}$ & $\begin{array}{l}\text { Proline, glycine betaine, total } \\
\text { phenolic contents, total } \\
\text { flavonoids, sorbitol, polyamines }\end{array}$ & $\begin{array}{l}{[21,23,} \\
29]\end{array}$ \\
\hline Drought & $\begin{array}{l}\text { Labisia pumila, Oryza sativa, } \\
\text { Salvia officinalis, Cichorium } \\
\text { intybus, Papaver somniferum, } \\
\text { Hypericum brasiliense, } \\
\text { Brassica juncea }\end{array}$ & $\begin{array}{l}\text { Phenols, monoterpenes, } \\
\text { essential oils, inulin, flavonoids, } \\
\text { anthocyanin, polyphenols, } \\
\text { rosmarinic, ursolic, oleanolic } \\
\text { acids }\end{array}$ & {$[30-35]$} \\
\hline $\begin{array}{l}\text { Heavy } \\
\text { metal }\end{array}$ & $\begin{array}{l}\text { Lepidium sativum, } \\
\text { Abelmoschus esculentus }\end{array}$ & $\begin{array}{l}\text { Lepidine, thiol, proline, total } \\
\text { phenolics, ascorbic acid content }\end{array}$ & {$[36,37]$} \\
\hline $\begin{array}{l}\text { High } \\
\text { temperature }\end{array}$ & $\begin{array}{l}\text { Dukus carota, Quercus rubra, } \\
\text { Medicago sativa L., } \\
\text { Camptotheca acuminata, } \\
\text { Crucifers }\end{array}$ & $\begin{array}{l}\text { Terpenes- } \alpha \text {-farnesene } \beta \text { - } \\
\text { caryophyllene, terpenes- } \\
\text { isoprene, quercetin, kaempferol, } \\
\text { agmatine and putrescine, } 10- \\
\text { hydroxycamptothecin }\end{array}$ & {$[38-42]$} \\
\hline $\begin{array}{l}\text { Low } \\
\text { temperature }\end{array}$ & $\begin{array}{l}\text { Salix, Triticum aestivum, } \\
\text { Medicago, Papaver } \\
\text { somniferum, Catharanthus } \\
\text { roseus, Pringlea } \\
\text { antiscorbutica, Prisms } \\
\text { sativum, Vaccinium myrtillus }\end{array}$ & $\begin{array}{l}\text { Terpenoids, putrescine, } \\
\text { spermidine, alkaloids-vindoline, } \\
\text { phenols-pelargonidin, agmatine } \\
\text { and putrescine, flavonoids }\end{array}$ & $\begin{array}{l}{[28,} \\
43-45]\end{array}$ \\
\hline Light & $\begin{array}{l}\text { Vanilla planifolia, Zingiber } \\
\text { officinale, Lactuca sativa, } \\
\text { Ipomoea batatas L. }\end{array}$ & $\begin{array}{l}\text { Vanillin, gingerol, zingiberene, } \\
\text { caffeoylquinic acids, } \\
\text { Chlorogenic acid, } \\
\text { hydroxybenzoic acids, } \\
\text { flavonoids }\end{array}$ & [46-49] \\
\hline UV-B & $\begin{array}{l}\text { Passiflora quadrangularis, } \\
\text { Fagopyrum esculentum and } \\
\text { Fagopyrum tataricum, } \\
\text { Populus trichocarpa }\end{array}$ & Flavonoids, phenolics & {$[50-52]$} \\
\hline
\end{tabular}

are involved in protective functions in response to both biotic and abiotic stress conditions. Abiotic stress-induced accumulation of phenyl amides, anthocyanin, and polyamines has been reported in the literature $[22,25]$. The change in the accumulation and composition of secondary metabolites in response to stress factors has been considered as an adaptive strategy leading to tolerance. For instance, the enhanced synthesis of saponins in Panax ginseng [22], serotonin in cold-exposed Datura flowers, and enhanced lignification of cell walls in many plant species are the examples of stress-induced accumulation of secondary metabolites [43-45]. A number of stresses are capable of redirecting the metabolism toward the accumulation of biologically active secondary metabolites. Besides, a number of researchers have applied various elicitors for enhancement of secondary metabolite production in cultures of plant cell, tissue, and organ [21]. 


\subsection{Influence of Temperature Stress on Secondary Metabolites}

Both low and high temperatures effect the metabolic process in plants. Plants often face challenges with high and low temperatures. While high temperatures induce premature leaf senescence and reduce membrane integrity, the rate of photosynthesis and biomass production in plants and low temperature leads to osmotic injury, desiccation, oxidative stresses, etc. [27, 38, 39, 41, 43]. In order to maximize their temperature tolerance, plant species adjust the metabolism to either increase or decrease the secondary metabolites. Low temperature induces the synthesis of several types of cryoprotectant compounds including nitrogenous compounds like proline, glycine and betaine; sugar alcohols like sorbitol, ribitol, and inositol; soluble sugars like saccharose, raffinose, stachyose, and trehalose; and low molecular weight to maintain the osmotic balance [53]. Leaves of wheat and alfalfa accumulate putrescine and spermidine when exposed to a low-temperature stress. Temperature stress also modulates alkaloid and phenolic compound production in several plant species [40, 41, 45]. For instance, cold acclimation in apple tree was reported to be associated with a marked increase in the accumulation of chlorogenic acid. In several plants, the enhanced phenolic production in turn results in the cell wall lignification or suberinization [54]. Similarly, higher levels of phenolic acid, anthocyanin, flavones, and antioxidant capacities were observed in strawberry, sugarcane, and lettuce when grown under elevated temperatures [54]. In addition, the total phenol level and especially the geneistin levels were observed highest after cold temperature treatment in soybean roots [55]. However, the low temperature reduced the accumulation of alkaloids such as morphine and benzylisoquinoline in Papaver somniferum [44, 45]. The anthocyanin and flavonoid biosynthesis was also promoted by low temperature in Zea mays seedlings and leaves of A. thaliana, Petunia hybrid, and Rosa hybrid $[55,56]$. It was further supported by the observed increase in the transcript accumulation of phenylpropanoid pathway genes including phenylalanine ammonia-lyase and chalcone synthase in Arabidopsis. Conversely, anthocyanin and carotenoid accumulation was reduced by high temperature in several species including Vitis vinifera and in Brassicaceae. This inhibition was partly attributed to the pigment degradation and reduced gene transcription under elevated temperature [56].

\subsection{Influence of Salt on Secondary Metabolites}

Salt stress is a global problem limiting agricultural production throughout the world [56]. Salt stress lead to cellular dehydration, ionic and osmotic stress in plants that subsequently results in accumulation or decrease of specific secondary metabolites. Salt stress is known to either induce or reduce the production of secondary metabolites to maximize the tolerance in plants [21, 23, 29]. Increased production of anthocyanins in Vitis vinifera cultures, polyphenols in Aegiceras corniculatum, 
tropane alkaloid in Datura innoxia, glycine betaine in Triticum aestivum, vincristine in Catharanthus roseus, and polyamines in Helianthus annuus are some examples of salinity-induced regulation of secondary metabolites [24, 57, 58]. Similarly a positive correlation between proline accumulation and salinity tolerance has been reported in tomato [29]. Salt-induced ABA is also a player in decreasing photosynthesis due to stomatal closure and plant growth inhibition under salt stress. Furthermore, higher salt concentration in growth media resulted in accumulation of high levels of terpenoids, phytoalexins, and zealexins, while lower salt concentration substantially induced the content of kauralexins in maize roots [56].

\subsection{Influence of Drought on Secondary Metabolites}

Drought stress is the major abiotic stress that can impact food production across the world [59]. Active accumulation of compatible solutes and osmoprotectants is the most common drought-induced metabolic adjustment in majority of the plants $[32,60]$. Besides the osmotic adjustment, reprogramming of plant metabolism also occurs in drought-stressed plants leading to multiple other changes in plant secondary chemistry $[30,33]$. Drought is known to induce an increase in secondary metabolites such as phenols, saponin, anthocyanin, and flavonoids in several plant species [30, 34, 35]. For instance, moderate water deficit enhanced saikosaponins in Bupleurum chinense and salvianolic acid in Salvia miltiorrhiza roots [31]. The content of glycine betaine and the total alkaloids in C. roseus plants increased due to drought in comparison with the unstressed control plants [61]. Drought-induced changes in secondary metabolite composition, including elevated tocopherol and carotenoid contents, have been associated with improve photoinhibition tolerance in several plants. Hence, the plants or plant tissues with anthocyanin or flavonoids are protected from drought [25]. Drought stress is also known to change the ratio of chlorophyll "a" and "b" and carotenoids [33-35].

Drought stress also increased the production of rosmarinic, ursolic, and oleanolic acid in Prunella vulgaris and betulinic acid content in Hypericum brasiliense [34, 35 ]. Similarly, the accumulation of alkaloids including narkotine, morphine, and codeine in P. somniferum was significantly increased due to drought. Drought effects can be associated with drought severity and vary for different compound classes. For instance, the total inulin percentage in Cichorium intybus roots increased by mild drought stress, whereas severe drought stress decreased inulin yield [32]. Another interesting study suggested more complex and differential regulation of secondary metabolites synthesized via shikimate and isoprenoid synthesis pathways in eucalypts [62]. In these plants drought had no effect on isoprenoids, monoterpenes, and sesquiterpenes, while condensed tannins were enhanced, and concentrations of macrocarpals decreased due to drought [57, 62]. Thus, all these studies underscore the need of more focused studies on secondary chemistry under various ecotypes and drought severities [59]. 


\subsection{Influence of Light on Secondary Metabolites}

Light is an important physical factor that can affect the growth and metabolite production [46]. Light is a natural elicitor for many secondary metabolites such as gingerol and zingiberene production in Zingiber officinale cultures, foliar tannins, and a number of phenolic glycosides [47]. High light irradiation has seen to induce anthocyanin production in cell suspension cultures of Perilla frutescens, apples, and light-colored sweet cherry [46, 62]. The effect of light was also evidenced from the digitoxin accumulation in Digitalis purpurea L., enhanced ginsenoside contents in American ginseng plants, and increased artemisinin production in hairy root cultures of Artemisia annua [62]. Light not only has stimulatory effect on the formation of secondary metabolites, including flavonoid and anthocyanins, but also influences the secretion mechanism of secondary products [47, 49, 62]. It has been reported that photoperiod also affect the secondary metabolite content in some plants such as Hypericum perforatum, in which maximal production of metabolites occurs at flowering stage. Similarly, blue light has stimulatory effect on the vanillin content in Vanilla planifolia [46].

Among various physical variables, ultraviolet (UV) irradiation was considered to be the major inducer of secondary metabolites in several plant species including peanut, rice, maize, and basil [51, 52]. UV-B has been seen to increase flavonoids in barley, several Passiflora species [50]. UV-B significantly increased the quercetin concentration in F. esculentum [51] and kaempferol in Populus trichocarpa leaves [52]. In rice, UV-tolerant cultivar accumulated more C-glycosylflavones compared to susceptible cultivar. Increased UV-B exposure stimulates the total phenolic content as phenolics offer UV protection in plants. Similar to UV-B, UV-C irradiation also is shown to be the stimulus for phenylpropanoid pathway-derived compounds and flavonoid synthesis [52].

\subsection{Influence of Heavy Metal on Secondary Metabolites}

Heavy metal contamination in soil, air, and water may alter the chemical and metabolite composition of plants leading to poor production and quality [15]. Metals such as aluminum, cadmium, lanthanum, nickel, europium, and silver are known to influence secondary metabolite production due to either inactivation or stimulation of enzymes involved in their production [36, 37]. For instance, metal ions in the growth medium regulate the anthocyanin biosynthesis by inhibiting activity of PAL [15]. $\mathrm{Cu}^{2+}$ and $\mathrm{Cd}^{2+}$ have been shown to induce secondary metabolites such as shikonin, digitalin, and betalains [63]. However, combined $\mathrm{Cd}$ and $\mathrm{Cu}$ treatment reduced the production of total phenolics, flavonoids, saponin, and overall medicinal properties due to the inhibition of PAL activity in $G$. procumbens $[15,63]$. Increases in heavy metal-induced secondary metabolite biosynthesis also result from increased synthesis of precursors [64]. At times heavy metal-induced stress activates the transcription of the genes encoding the secondary metabolites synthesis which subsequently contribute to the defensive reactions of the plant [15]. In silver ion- 
exposed Brugmansia candida root culture, there is an increase in scopolamine due to the downregulation of the enzyme hyoscyamine-6- $\beta$-hydroxylase responsible for scopolamine release [65]. This can also be partly due to the metal-induced regulation of signaling molecules such as ethylene which in turn can regulate the production of tropane alkaloids such as scopolamine. Similarly heavy metals are also known to stimulate the activity of ethylene biosynthesis genes, 1-aminocyclopropane-1-carboxylic acid synthase, and oxidase either directly or through the jasmonate-mediated pathway [66]. In another study [67] also suggested a positive correlation between the increase in signal molecules with an increase of secondary metabolites under $\mathrm{Cu}^{2}$ ${ }^{+}$exposure. Similarly, the increase in the synthesis and metabolism of phenolic compounds under $\mathrm{Pb}$ stress was reported in Phaseolus vulgaris. The $\mathrm{Pb}$-induced increase in phenolic content was thought to protect plants from oxidative damage and membrane lipid per oxidation. Plants growing in aluminum-rich soils also accumulate a lot of flavonoids in order to prevent oxidative stress [25]. It is clear from these studies that alteration in secondary metabolism may be a strategy of the plant to survive the phytotoxicity of heavy metals.

\section{$3 \quad$ Abiotic Stress and Nitric Oxide}

NO has gained significant attention in recent years due to its potentiality in enhancing tolerance of plants to various environmental stresses $[2,12,13]$. As a redox molecules, $\mathrm{NO}$ can function both as a positive and negative regulator of stress responses depending on the local concentration. Being a free radicle, NO plays a powerful role in activating ROS-scavenging enzyme activities and protecting from oxidative damage under abiotic stress. Studies in the recent past have established the role of NO in resistance to salt, drought, extreme temperature, UV$\mathrm{B}$, and heavy metal stress (Table 2; [12, 13, 74]). Although the complete mechanism by which NO reduces abiotic stress is yet to be deciphered, a definite role of $\mathrm{NO}$ is suggested in several physiological processes. In fact, an enhancement of endogenous NO accumulation has been observed in several plant species exposed to wide variety of stress responses providing evidence that endogenous NO could be actually involved in plant stress responses [2]. Although accumulation of $\mathrm{NO}$ during various stress conditions appears to be a general response in diverse plant species and tissues, its specificity has been established by using various inhibitors/scavengers such as c-PTIO or L-NAME which reversed these NO-mediated effects in many such studies [2, 69]. Furthermore, exogenous supplementation of NO donors including SNP, SNAP, and diethylenediamine have reported to offer protective actions against abiotic stress, while NO scavengers/inhibitors reversed these actions [12, 84]. Most of the abiotic stresses lead to oxidative burst that disrupt the cellular redox homeostasis. NO may act as a chain breaker and provide protection against oxidative damage under given stress. Being lipolytic small molecules, NO can easily cross cell barriers and enhance cell communications under stress. NO can directly or indirectly interact with a wide range of targets due to the number of posttranslation modifications such as $S$-nitrosylation and nitration [79]. Several transcription factors involved in the regulation of abiotic stress responses in plants including MYB family 
Table 2 Various studies describing the involvement of nitric oxide (NO) in plant abiotic stress tolerance

\begin{tabular}{|c|c|c|c|}
\hline Stress & Plant species & NO response & References \\
\hline Drought & $\begin{array}{l}\text { Arabidopsis thaliana, } \\
\text { Medicago truncatula, } \\
\text { Tagetes erecta, Oryza sativa }\end{array}$ & $\begin{array}{l}\text { Synthesis of ROS and NO, } \\
\text { involved in ABA signaling, } \\
\text { stomatal movement, late } \\
\text { embryogenesis abundant protein } \\
\text { expression, enhanced antioxidant } \\
\text { defense and osmolytes, increased } \\
\text { adventitious root length, reduced } \\
\text { lipid peroxidation }\end{array}$ & $\begin{array}{l}{[2,20,} \\
68-72]\end{array}$ \\
\hline Salt & $\begin{array}{l}\text { Cucumis satyas, Oryza } \\
\text { sativa, Brassica nigra, } \\
\text { Glycine max, Gossypium } \\
\text { hirsutum }\end{array}$ & $\begin{array}{l}\text { Survival of more green leaf tissue, } \\
\text { and increased quantum yield for } \\
\text { photosystem II, increased } \\
\text { germination rate and root growth, } \\
\text { reduced lipid peroxidation, } \\
\text { enhanced antioxidants, altered } \\
\text { gene transcription, enhanced } \\
\text { photosynthesis }\end{array}$ & [73-77] \\
\hline $\begin{array}{l}\text { Low } \\
\text { temperature }\end{array}$ & $\begin{array}{l}\text { Helianthus annuus, } \\
\text { Capsicum annum, Oryza } \\
\text { sativa, Citrus sp., Cucumis } \\
\text { sativus } \text { L. }\end{array}$ & $\begin{array}{l}\text { Increase in endogenous NO } \\
\text { production in wild types, decline } \\
\text { the ROS level, synthesis of } \\
\text { osmolytes, reprogramming of } \\
\text { lipid signaling, negatively } \\
\text { regulates sphingolipid } \\
\text { phosphorylation, increases } \\
\text { spermidine and spermine levels }\end{array}$ & [78-82] \\
\hline $\begin{array}{l}\text { High } \\
\text { temperature }\end{array}$ & $\begin{array}{l}\text { Oryza sativa, Citrus } \mathrm{sp} ., \\
\text { Cucumis sativus L., Festuca } \\
\text { arundinacea }\end{array}$ & $\begin{array}{l}\mathrm{NO} \text { acts as signal molecule for the } \\
\text { stress response, protects the plant } \\
\text { from heat stress-induced } \\
\text { oxidative stress, plays an } \\
\text { important role in } \\
\mathrm{H}_{2} \mathrm{O}_{2} \text { metabolism } \\
\text { ROS-scavenging enzymes, } \\
\text { alleviated the expression of HSPs, } \\
\text { and acts as signal molecule for the } \\
\text { stress response }\end{array}$ & $\begin{array}{l}{[12,74,} \\
78,82,83]\end{array}$ \\
\hline Metal & $\begin{array}{l}\text { Triticum aestivum, Glycine } \\
\max \end{array}$ & $\begin{array}{l}\text { Noticed that SNP pretreatment } \\
\text { significantly reduced } \mathrm{O}_{2} \text {-induced- } \\
\text { specific fluorescence, increased } \\
\text { the root elongation, reduced the } \\
\text { NOS activity }\end{array}$ & [84-87] \\
\hline $\begin{array}{l}\text { Ozone } \\
\text { stress }\end{array}$ & $\begin{array}{l}\text { Arabidopsis thaliana, } \\
\text { Popules } \mathrm{sp} .\end{array}$ & $\begin{array}{l}\text { Exogenous application or } \\
\text { endogenous synthesis of } \mathrm{NO} \\
\text { reduces the damaging effects of } \\
\text { ozone by activating active oxygen } \\
\text { scavenging enzymes }\end{array}$ & {$[88,89]$} \\
\hline UV & $\begin{array}{l}\text { Betula pendula, Arabidopsis } \\
\text { thaliana, Zea mays }\end{array}$ & $\begin{array}{l}\text { Increased accumulation of } \\
\text { putrescine, spermine, and } \\
\text { spermidine, reduced lipid } \\
\text { peroxidation, activation of } \\
\text { antioxidant enzymes, increased } \\
\text { osmotic tolerance }\end{array}$ & [90-92] \\
\hline
\end{tabular}


transcription factors and protein kinases are regulated through S-nitrosylation. It can also trigger several redox-based signaling while altering expression of several genes involved in plant defense. NO upregulated the activity and transcription of APX and GR, the two key enzymes in the ascorbic acid-glutathione (AsA-GSH) cycle in Nicotiana tabacum and Cucumis sativus leaves, and conferred resistance to abiotic stress [93].

It has been reported that even mild water deficit also leads to the accumulation of $\mathrm{NO}$ in cucumber roots [2]. Moreover, accumulation of $\mathrm{NO}$ as a result of application of exogenous donors in many reported studies also correlated well with the amelioration of drought stress, while the use of $\mathrm{NO}$ scavengers/inhibitors reversed this effect [68]. Exogenous NO improved drought tolerance by reducing stomatal opening, membrane damage, and lipid peroxidation in water-stressed plants [2]. Application of SNP enhanced plant tolerance to drought by inducing stomatal closure, reducing transpiration rate, thereby lowering water loss in leaves and protein synthesis, enhancing photosynthesis rate, and increasing the activities of ROSscavenging enzymes [69].A good number of studies confirmed the generation of $\mathrm{NO}$ in guard cells in response to drought and ABA by using a NO-sensitive fluorescent dye DAF-2DA [70]. The increase in NO production under drought stress has been correlated significantly to the decrease in stomatal conductance in Vitis vinifera. Additionally, NO decreased drought-induced reduction in photochemical quenching during adventitious rooting in explants of Tagetes erecta [71]. Similarly, NO-treated Dendrobium huoshanense plants maintained high levels of antioxidant enzyme activities and less lipid peroxidation under drought stress [2]. Not only that, NO also help in maintaining high vacuolar concentrations of osmotically active solutes and amino acids under drought. NO promoted drought-induced free proline accumulation in Oryza sativa, Ginkgo biloba, and Triticum aestivum [72]. Similarly, accumulation of glycine betaine was also promoted by NO-mediated stimulation of betaine aldehyde dehydrogenase activity in the leaves of drought-stressed Zea mays [72]. Moreover, transgenic plants overexpressing the rat neural nitric oxide synthase gene in $A$. thaliana and $O$. sativa exhibit enhanced drought tolerance than their respective untransformed controls $[2,20]$.

More than 45 million hectares of cultivated land globally has been contaminated with high salinity limiting the plant water and mineral uptake. Previous research suggested that exogenous application of NO donors could enhance salinity tolerance in a number of plant species including Phragmites communis, Lupinus luteus, tobacco, sunflower, cucumber, wheat, and rice $[73,74,76,77]$. In most cases, an enhancement of endogenous $\mathrm{NO}$ levels is followed by $\mathrm{Na}^{+}$exclusion and improved $\mathrm{K}^{+} / \mathrm{Na}^{+}$ratios. On the other hand, Arabidopsis noal mutant with lower NO level was more sensitive to $\mathrm{NaCl}$ further supporting the need of $\mathrm{NO}$ in salinity tolerance. Further SNP-induced antioxidant enzymes provided resistance to salt stress by alleviating the oxidative damage in many plant species including rice seedlings, cucumber, maize, etc. $[73,74,76]$. Besides, NO participates in enhancement of photosynthesis by inducing the photosynthetic pigments and adenosine triphosphate synthesis, by quenching excess energy, and by increasing in quantum yield of PSII by using exogenous NO in Solanum melongena seedlings under salt stress [75, 77]. 
Participation of $\mathrm{NO}$ in plant response to temperature extremes is also well documented in literature [12]. An increase in NO synthesis associated with cold acclimation was observed in Helianthus annuus and Capsicum annuum $[12,74,79,80]$. Transgenic cucumber plants overexpressing CsNOA1 constitutively had greater accumulation of soluble sugars and starch and a lower chilling damage index, while suppression of CsNOA1 expression resulted in opposite effects [78]. Furthermore, exogenous application of an NO donor can induce cold acclimation through synthesis of osmolytes such as glycine betaine and proline and reprogramming of lipid signaling and composition [74, 81]. Similarly, high-temperature treatment increased NO levels in leaves of Nicotiana tabacum and Medicago sativa [9]. While exogenous $\mathrm{NO}$ has been able to reduce heat-induced cellular damage, depleting endogenous NO levels by cPTIO reversed these beneficial effects $[12,84]$. SNP treatment recovered relative water content, chlorophyll content, and electrolyte leakage in heat-stressed Zingiber officinale, Festuca arundinacea, Triticum aestivum, and Zea mays [12, 82, 83]. NO plays a significant role in mitigating heat-induced oxidative stress in plants by maintenance of cellular redox hemostasis and through moderation of carotenoid content [68].

NO mitigate heavy metal stresses in plants mainly by upregulation of antioxidant defense, by regulating cellular free metal concentration, or by excluding the heavy metal in the root zone, thereby preventing the accumulation at toxic concentrations $[15,84-86]$. SNP supplementation decreased Cd accumulation in roots and stems while increasing the photosynthetic and antioxidant activity in Arachis hypogaea [15]. In rice, exogenous NO treatment has increased $\mathrm{Cd}$ tolerance by increasing pectin and hemicellulose content in the root cell walls and decreasing Cd sequestration in leaf soluble fractions [85]. Moreover, the involvement of NO has also seen in protection of chlorophyll against $\mathrm{Cd}$ stress in $\mathrm{H}$. annuus and $\mathrm{Cu}$ stress in Lolium perenne [86]. Similarly, NO treatment raised photosynthetic rate, antioxidant activity, and reduced MDA content in Vigna unguiculata and antioxidant gene transcription in Triticum aestivum under Al stress [87]. NO also plays a critical role in promoting antioxidant enzymes activities and inducing the activity of $\mathrm{H}^{+}$-ATPase under metals stress in tomato plants. The role of NO in alleviating other heavy metals has been reviewed by few authors in recent years $[15,86]$.

Ozone exposure induced NO generation and flavonol accumulation in Ginkgo biloba cells [3]. Further, a study in poplar has indicated increased activity of phenylalanine ammonia-lyase (PAL) due to de-nitrosylation and also $S$ nitrosylation of nearly 172 proteins due to ozone fumigation [89]. Similarly studies indicate that upregulation of flavonoids and chalcone synthase gene responsible for flavonoid production by UV-B requires NO in A. thaliana and Betula pendula plants [90]. Pretreated with SNP prevented the oxidative stress progression in UV-Bexposed Phaseolus vulgaris seedlings by decreasing $\mathrm{H}_{2} \mathrm{O}_{2}$ content, increasing the thiol group content, and upregulation of active oxygen scavenging genes [91]. These studies suggest that UV-B-enhanced NO levels protect the microtubule organization as well as microtubule-related processes by in-plant cells against disrupting effects of UV-B [92]. All these evidence presents NO as a key regulator in maintaining cellular osmotic and redox status in plants under stress. 


\section{$4 \quad$ Role of NO in Inducing Secondary Metabolites}

Biosynthesis of plant secondary metabolites is regulated by multiple endogenous signaling pathways. NO has been widely utilized as elicitor to stimulate secondary metabolite accumulation in several plants ([94, 95]; Table 3). Priming with SNP has enhanced the phenolic and flavonoid content in fenugreek seeds [116]. Similarly, SNP priming of ripe litchi fruits enhanced the shelf life due to the enhancement of the total phenolic content during postharvest storage [117]. NO is known to regulate the production of many pharmaceutically important secondary metabolites in plants [95]. Rhodiola sachalinensis A. Bor. is a perennial herb popularly known for its traditional medicinal properties in China. Nitric oxide induced the bioactive metabolites including salidroside in this endangered plant while increased the total content of phenolic and flavonoid compounds in lemon balm seedlings under in vitro conditions [101]. In another study, the effect of NO donor was studied on the content of secondary metabolites in Calendula officinalis L. SNP treatment had significant role in production of total phenolic and flavonoid content, antioxidant activity, and essential oil of capitule, while it had no effect on other pigment content. The application of NO donors for induction of the secondary metabolite production in plant cultures is also becoming increasingly popular [95]. To give few examples, SNP treatment induced catharanthine production in Catharanthus roseus cells [94, 96 ]. Similarly, the hypericin production by Hypericum perforatum was significantly enhanced by at least fourfold after eliciting with NO [96, 105]. The accumulation of secondary metabolite such as tannins, saponins, phenols, and total flavonoids is significantly enhanced by high doses of SNP in Ginkgo biloba callus cultures [106]. The accumulation of phenolic compounds and glycosides is subsequently followed by an oxidative burst and subsequent activation of specific enzymes activities such as PAL, SOD, and APX in Gingko biloba [118]. SNP treatment elicited the accumulation of secondary metabolites in Echinacea purpurea adventitious roots. Exogenous treatments with SNP also enhanced the accumulation of phenolics, flavonoids, and caffeic acid derivatives in this species suggesting the importance of NO accumulation for the secondary metabolic production [100]. Moreover, the involvement of NO was also suggested in the accumulation of artemisinin in hairy root cultures of Artemisia annua L. and taxol production from Taxus chinensis cell cultures [119, 120]. Many previous studies have shown that NO is being involved in elicited production of secondary metabolites such as ginseng saponin, hypericin, puerarin, catharanthine artemisinin, and taxanes in plant cell and tissue cultures [94, 96, $101-103,105,120,121]$. These metabolites are highly valuable components of pharmaceuticals and nutraceuticals. The production and isolation of secondary metabolites from Ficus religiosa L. in tissue culture are often challenged by callus browning [122]. Adding SNP to the MS medium along with 2,4dichlorophenoxyacetic acid and 6-benzyl amino purine significantly reduced the accumulation of hydrogen peroxide and phenolic compounds in the callus tissues. Similarly, exogenous NO promoted callus induction and reduced browning of Chinese yam. Hence, complete elucidation of its role in the production of such pharmaceutically significant secondary metabolites is crucial for improving the large-scale commercial production. 
Table 3 Studies describing the role of NO and abiotic cues in eliciting the synthesis of secondary metabolites in plants

\begin{tabular}{|c|c|c|c|c|}
\hline Plant species & Stress & $\begin{array}{l}\text { NO } \\
\text { elicitation }\end{array}$ & Target metabolites & References \\
\hline Catharanthus roseus & - & SNP & Catharanthine & {$[96]$} \\
\hline $\begin{array}{l}\text { Scutellaria } \\
\text { baicalensis }\end{array}$ & - & SNP & Baicalin & [97] \\
\hline Tagetes erecta & - & SNP & Phenol and antioxidants & [98] \\
\hline Sophora flavescens & - & SNP & Matrine & [99] \\
\hline $\begin{array}{l}\text { Onosma } \\
\text { paniculatum Bur. } \\
\text { et Franch }\end{array}$ & - & SNP & Shikonin products & {$[100]$} \\
\hline $\begin{array}{l}\text { Rhodiola } \\
\text { sachalinensis A. } \\
\text { Bor. L. }\end{array}$ & - & SNP & Salidroside & {$[101]$} \\
\hline Artemisia anпиа L. & - & SNP & Artemisinin & [102] \\
\hline Atractylodes lancea & - & SNP & $\begin{array}{l}\text { Volatile oil ( } \beta \text {-eudesmol, } \\
\text { atractylone, and } \\
\text { atractylodin) }\end{array}$ & {$[103,104]$} \\
\hline $\begin{array}{l}\text { Hypericum } \\
\text { perforatum }\end{array}$ & $\begin{array}{l}\text { High } \\
\text { temperature }\end{array}$ & SNP & $\begin{array}{l}\text { Improve hypericin } \\
\text { production }\end{array}$ & {$[105]$} \\
\hline Ginkgo biloba & UV-B & SNP & Phenols, acids, flavonoids & {$[106]$} \\
\hline Zea mays & UV-B & cPTIO & Flavonoids & [92] \\
\hline Pisum sativum $\mathrm{L}$. & UV-B & NO & Cell wall polysaccharides & [107] \\
\hline Taxus chinensis & UV-B & $\begin{array}{l}\text { SNP, } \\
\text { cPTIO }\end{array}$ & $\begin{array}{l}\text { Flavonoids, condensed } \\
\text { tannins, total phenolics, and } \\
\text { taxol }\end{array}$ & [108] \\
\hline $\begin{array}{l}\text { Achillea species, } \\
\text { Ginkgo biloba, Vitis } \\
\text { vinifera }\end{array}$ & Drought & - & $\begin{array}{l}\text { Total phenolic, flavonoid, } \\
\text { soluble proteins, lignin }\end{array}$ & [109-111] \\
\hline $\begin{array}{l}\text { Spinacia oleracea, } \\
\text { Solanum } \\
\text { lycopersicum }\end{array}$ & Salt & NO & $\begin{array}{l}\text { Total phenolics, flavonoids, } \\
\text { osmolytes, carotenoids }\end{array}$ & {$[112,113]$} \\
\hline Vicia faba & Arsenic & NO & $\begin{array}{l}\text { Photosynthetic pigments, } \\
\text { phenols, phytohormones, } \\
\text { minerals }\end{array}$ & [114] \\
\hline Glycine max & $\begin{array}{l}\text { Low } \\
\text { temperature }\end{array}$ & - & Phenols, genistein, daidzein & {$[55]$} \\
\hline $\begin{array}{l}\text { Camptotheca } \\
\text { acuminata }\end{array}$ & $\begin{array}{l}\text { High } \\
\text { temperature }\end{array}$ & - & $\begin{array}{l}\text { Alkaloids- } 10- \\
\text { hydroxycamptothecin }\end{array}$ & [41] \\
\hline Helianthus annuus & $\begin{array}{l}\text { High } \\
\text { temperature }\end{array}$ & NO & S-nitrosothiols & [79] \\
\hline $\begin{array}{l}\text { Chlamydomonas } \\
\text { reinhardtii }\end{array}$ & $\mathrm{Cu}^{+2}$ & SNP & Proline & [115] \\
\hline $\begin{array}{l}\text { Trigonella foenum- } \\
\text { graecum }\end{array}$ & $\begin{array}{l}\text { Oxidative } \\
\text { stress }\end{array}$ & SNP & Phenolics, flavonoids & [116] \\
\hline
\end{tabular}




\subsection{NO-Mediated Elicitation of Secondary Metabolites Under Abiotic Stress}

Several studies (mentioned in above sections) have demonstrated the alteration in the secondary metabolite profile under abiotic stress in plants. NO can also increase production of secondary metabolites and activate plant protection systems even under stress conditions [94, 114]. Several abiotic and biotic elicitors can induce NO-mediated regulation of the biosynthetic pathways of metabolites that can consequently alter growth and development in plants [95]. However, very little is known on NO signaling in the biosynthesis of plant secondary metabolites under stress. Given the production of NO in plants in response to abiotic and biotic stresses [106, $107,111,123$ ], it can be presumed that NO may have the most possible and prominent role in inducing secondary metabolites in response to stress. Hence, the elicitor or stress-induced NO production is essential for triggering the biosynthesis of critical secondary metabolites in plants [95]. $\mathrm{Cu}^{2+}$ stress could induce NO production and subsequent proline accumulation in Chlamydomonas reinhardtii and in roots of $P$. ginseng [115]. In another study, ultrasound treatment for $2 \mathrm{~min}$ resulted in a rapid and dose-dependent $\mathrm{NO}$ production in T. yunnanensis cell cultures which in turn stimulated the production of taxol and baccatin III [120].

An interesting study suggested that NO treatment created a strong demand for cysteine synthesis as a way to reduce oxidative stress. Cysteine synthesis is one of the rate-limiting steps for the formation of glutathione which is very crucial component in cellular redox responses. In agreement with that, active synthesis of amino acids specifically $\alpha$-ketoglutarate-derived amino acids of the glutamate family was evident in response to NO treatment [94]. It is known from earlier reports that the metabolism of $\gamma$-aminobutyrate (GABA) is crucial plants exposed to low oxygen or high light condition. Exposure of plants to NO showed a moderate increase in the levels of GABA and 2-aminobutyrate and the significant increase for $\gamma$ hydroxybutyrate.

A recent metabolomic data suggested a significant increase in metabolites involved in purine and pyrimidine metabolism by $6 \mathrm{~h}$ after NO treatment. There was a significant increase in the levels of allantoin, guanine, urate, cytidine, cytosine$2^{\prime}, 3^{\prime}$-cyclic monophosphate, pseudouridine, uridine, and uracil by NO. On the other hand, NO treatment induced chlorophyll degradation as evident by an increment in the levels of pheophorbide, a breakdown intermediate product of chlorophyll in plants [19, 124].

$\mathrm{NO}$ is one of those key signaling molecules in elicitor-induced secondary metabolite biosynthesis in plant cells. Although pharmacological experiments with NO donor and scavenger showed that the occurrence of NO contributes to strengthening the transcription of genes encoding key enzymes involved in the biosynthesis of those target secondary metabolites such as shikonin [100], little effort has been put onto revealing the signal transduction steps underlying NO activation of plant secondary metabolism. PAL is the critical enzyme that mediates the conversion of phenylalanine into trans-cinnamate, from which many plant phenolic compounds originate [125]. In several studies, more plant phenolic compounds are produced 
with increased PAL activity [120]. It has been clearly demonstrated that NO stimulates transcription of the PAL gene in plants [125]. Increased PAL production means greater efficiency in converting phenylalanine into phenolic compounds; and, therefore, in most cases, concentrations of plant phenolic compounds increase following the use of NO. In T. chinensis cell cultures, NO enhanced PAL activity while inhibiting the transcription of strictosidine synthase and tryptophan decarboxylase by inducing zinc finger-binding proteins [120]. Besides, exogenous NO donor SNP is known to induce the expression levels of 4-hydroxybenzoate metageranyltransferase and 3-hydroxy-3-methylglutaryl CoA reductase involved in shikonin biosynthesis in O. paniculatum cells [100].

Some abiotic stress-eliciting responses, including ROS production, lipid peroxidation, the activation of PAL, and osmolyte production, were also mediated by NO. For example, exogenous NO treatment enhanced the production of antioxidation-associated compounds, total phenolic content, proline, and flavonoids in salt-stressed spinach and tomato [111-113]. Furthermore, exogenous NO application has also increased the fresh and dry biomasses of edible parts compared to salt alone treated plants. Given the results in spinach, the authors have proposed the application of nitric oxide gas as an effective strategy for boosting biomass production and nutrition quality in spinach under salt stress. NO donor has also been proven to exert a protective effect against polyethylene glycol-induced drought stress in wheat seedlings by enhancing growth, relative water content, and reducing oxidative damage [2]. Similarly, heat shock in $H$. perforatum suspension cells induced NO production subsequently resulting in hypericin production [105].

The most common protective mechanism against UV irradiation is the biosynthesis of UV-absorbing secondary metabolites [106]. Several reports indicated the protective effect of $\mathrm{NO}$ against oxidative stress under UV-B irradiation [90, 91 ]. The role of $\mathrm{NO}$ in the regulation of flavonoid biosynthesis in G. biloba leaves under the UV-B was elucidated by [106]. Additionally, the sequential occurrence of NO production via increased NOS activity and increased chalcone synthase has been suggested [94]. A similar observation was noted in pea seedlings, where UV-B induced NR activity and NO production inhibited stem elongation due to the inhibition of xyloglucan-degrading activity [107]. In Taxus chinensis, spraying SNP and cPTIO had significant effect on the contents of photosynthetic pigments and taxol production [108]. Interestingly high levels of flavonoids, condensed tannins, total phenolics, and taxol were noted under UV-B + cPTIO treatment suggesting the requirement of balanced levels of $\mathrm{NO}$ in the secondary metabolism.

Use of fungal elicitors is one of the most effective strategies for inducing economically important secondary metabolites in plants. A study by [103] has shown that $\mathrm{NO}$ mediates violate oil accumulation induced by the endophytic fungus Gilmaniella sp. through salicylic acid and $\mathrm{H}_{2} \mathrm{O}_{2}$-dependent pathways in plantlets of Atractylodes lancea. Furthermore pretreatment of plantlets with exogenous NO donor promoted volatile oil accumulation, while treatment with NO scavenger inhibited the burst of salicylic acid and volatile oil accumulation induced by the fungus. Likewise elicitation with another endophytic fungal Cunninghamella sp. also induced the NO-mediated accumulation of atractylone, hinesol, $\beta$-eudesmol, and atractylodin in suspension cells of $A$. lancea [104]. NO induced by cerebroside 
elicitor from Fusarium was involved in the regulation of artemisinin production by increasing the gene expression of 1-deoxy-D-xylulose 5-phosphate synthase and hydroxybenzoate meta-geranyltransferase in $A$. annua hairy roots as well [102]. It was reported that oligogalacturonic acid-induced NO accumulation could improve the transcription of squalene synthase and squalene epoxidase, two early enzymes for the synthesis of triterpenoid saponins in cell cultures of Panax ginseng [121]. Similarly, NO burst followed by the biosynthesis of torpinoid $\beta$-thujaplicin in elicited Cupressus lusitanica cells which has strong antifungal, antiviral, and anticancer activities [126]. NO was found to reduce the transcription of genes in the monoterpenoid indole alkaloids pathway and the octadecanoid-responsive Catharanthus AP2/ERF domain transcription through the inhibition of type-I protein prenyltransferase gene, leading to a downregulation of the catharanthine biosynthesis [96].

NO may also interact with other signaling molecules integral of plant defense system including jasmonic acid, ethylene, salicylic acid, and ROS while taking part in elicitor-induced production of secondary metabolites [94, 126]. Although these molecules operate through distinct defense signaling pathways, they are all known to interact with $\mathrm{NO}$ in mediating plant secondary metabolite production [126]. The combination of elicitation with various biotic, abiotic stresses, and other signal molecules implies $\mathrm{NO}$ as the keypoint in the signaling network leading to the biosynthesis of some secondary metabolites [95]. Jasmonic acid induce NOS activity and subsequent NO production leading to enhanced matrine accumulation in Sophora flavescens suspension cells [99]. Similarly, NO-mediated accumulation of fungal elicitor-induced puerarin production in $P$. thomsonii suspension cells occurs through both SA-dependent or SA-independent signaling pathways [94, 95]. Although a direct link between methyl jasmonate and NO is yet to establish, exogenous MeJA triggered a burst of NO during the accumulation of taxol from $T$. chinensis cell cultures. Furthermore the suppression of NO by its inhibitors also suppressed the MeJA-induced taxol production suggesting a central role of NO in taxol accumulation [120]. Similarly, NO acts downstream to MeJA during the accumulation of four tanshinone compounds in hairy root cultures of Salvia miltiorrhiza [127]. However, SNP supplementation along with methyl jasmonate leads to the marked decrease of the catharanthine production by repressing the transcription of its biosynthetic genes, while methyl jasmonate supplementation alone stimulated the transcription of catharanthine pathway genes suggesting an antagonistic relation between NO and MeJA [127].

NO acts synergistically with reactive oxygen species to stimulate ethylene biosynthesis and stomatal closure in defense response to UV-B irradiation in maize leave [92]. In another study, brassinolide pretreatment induced the production of NO prior to the upregulation of cold-related gene expression and antioxidant enzymes activities in Medicago truncatula plants during cold stress tolerance. Further, brassinolide inhibitor reduced NO production and the expression of brassinolideinduced mitochondrial alternative oxidase, photosystem II efficiency, and homeostasis secondary metabolites accumulation [128]. This suggests that production of secondary metabolites or phytosignalling molecules may be the mechanism through which NO exerts its protecting effect from abiotic stress in plants. 


\section{Conclusions}

Alteration in secondary metabolism is an effective strategy of the plants to survive and grow in adverse conditions [56]. Many studies indicated the influence of abiotic stress on the amounts of phenolic compounds, flavonoids, glucosinolates, antioxidants, osmolytes, carotenoids terpene derivatives, and phytohormones in plants. NO has been reported to be induced rapidly by abiotic and biotic elicitors in a variety of plant species. Although several studies evidence the role of secondary metabolites and NO in plant's response to various abiotic stress factors, the knowledge about NO-mediated secondary metabolome alterations in abiotic stressed plants is still in its infancy. Few recent studies have shown that exogenous addition of NO can enhance the effect of abiotic elicitors on plant secondary metabolite production. Moreover, different NO donors could be chemically synthesized to be used as a priming agents or elicitor for industrial production of important secondary metabolites in plant culture systems. The NO elicitation can be an effective strategy to significantly improve specificity and efficiency of the production of desired metabolites. Hence, complete understanding of the signal transduction pathways underlying NO-induced production of secondary metabolites not only advance our understanding but also is important for optimizing the commercial production of metabolites which are difficult to be obtained by chemical synthesis.

Acknowledgments This work was supported by a financial support to authors from the CGIAR Research Program on Genetic Gains.

\section{References}

1. Vile D, Pervent M, Belluau M, Vasseur F, Bresson J, Muller B, ... Simonneau T (2012) Arabidopsis growth under prolonged high temperature and water deficit: independent or interactive effects. Plant Cell Environ 35(4):702-718. https://doi.org/10.1111/j.13653040.2011.02445

2. Santisree P, Bhatnagar-Mathur P, Sharma KK (2015) NO to drought-multifunctional role of nitric oxide in plant drought: do we have all the answers. Plant Sci 239:44-55. https://doi.org/ 10.1016/j.plantsci.2015.07.012

3. Monks PS, Archibald AT, Colette A, Cooper O, Coyle M, Derwent R, ... Stevenson DS (2015) Tropospheric ozone and its precursors from the urban to the global scale from air quality to short-lived climate forcer. Atmos Chem Phys 15(15): 8889-8973. https://doi.org/ 10.5194/acp-15-8889

4. Hayat S, Hayat Q, Alyemeni MN, Wani AS, Pichtel J, Ahmad A (2012) Role of proline under changing environments. Plant Signal Behav 7(11):1456-1466. https://doi.org/10.4161/ psb. 21949

5. Atkinson NJ, Urwin PE (2012) The interaction of plant biotic and abiotic stresses: from genes to the field. J Exp Bot 63(10):3523-3543. https://doi.org/10.1093/jxb/ers100

6. Klepper L (1979) Nitric oxide (NO) and nitrogen dioxide $\left(\mathrm{NO}_{2}\right)$ emissions from herbicidetreated soybean plants. Atmos Environ 13(4):537-542. https://doi.org/10.1016/0004-6981(79) 90148-3

7. Baudouin E (2011) The language of nitric oxide signalling. Plant Biol 13(2):233-242. https:// doi.org/10.1111/j.1438-8677.2010.00403 
8. Arc E, Galland M, Godin B, Cueff G, Rajjou L (2013) Nitric oxide implication in the control of seed dormancy and germination. Front Plant Sci 4:346. https://doi.org/10.3389/fpls. 2013.00346

9. Yu M, Lamattina L, Spoel SH, Loake GJ (2014) Nitric oxide function in plant biology: a redox cue in deconvolution. New Phytol 202(4):1142-1156. https://doi.org/10.1111/nph.12739

10. Corpas FJ, Leterrier M, Valderrama R, Airaki M, Chaki M, Palma JM, Barroso JB (2011) Nitric oxide imbalance provokes a nitrosative response in plants under abiotic stress. Plant Sci 181(5):604-611. https://doi.org/10.1016/j.plantsci.2011.04.005

11. Asgher M, Per TS, Masood A, Fatma M, Freschi L, Corpas FJ, Khan NA (2017) Nitric oxide signaling and its crosstalk with other plant growth regulators in plant responses to abiotic stress. Environ Sci Pollut Res Int 24(3):2273-2285. https://doi.org/10.1007/s11356016-7947-8

12. Parankusam S, Adimulam SS, Bhatnagar-Mathur P, Sharma KK (2017) Nitric oxide (NO) in plant heat stress tolerance: current knowledge and perspectives. Front Plant Sci 13(8):1582. https://doi.org/10.3389/fpls.2017.01582

13. Fancy NN, Bahlmann AK, Loake GJ (2017) Nitric oxide function in plant abiotic stress. Plant Cell Environ 40(4):462-472. https://doi.org/10.1111/pce.12707

14. Negi S, Santisree P, Kharshiing EV, Sharma R (2010) Inhibition of the ubiquitin proteasome pathway alters cellular levels of nitric oxide in tomato seedlings. Mol Plant 3(5):854-869. https://doi.org/10.1093/mp/ssq033

15. Sahay S, Gupta M (2017) An update on nitric oxide and its benign role in plant responses under metal stress. Nitric Oxide 67:39-52. https://doi.org/10.1016/j.niox.2017.04.011

16. Mur LA, Mandon J, Persijn S, Cristescu SM, Moshkov IE, Novikova GV, . . Gupta KJ (2013) Nitric oxide in plants: an assessment of the current state of knowledge. AoB Plants 5. https:// doi.org/10.1093/aobpla/pls052

17. Foresi N, Mayta ML, Lodeyro AF, Scuffi D, Correa-Aragunde N, García-Mata C, ... Lamattina L (2015) Expression of the tetrahydrofolate-dependent nitric oxide synthase from the green alga Ostreococcus tauri increases tolerance to abiotic stresses and influences stomatal development in Arabidopsis. Plant J 82(5):806-821. https://doi.org/10.1111/ tpj. 12852

18. Röszer T (2012) The biology of subcellular nitric oxide. Springer Science \& Business Media, Dordrecht. https://doi.org/10.1007/978-94-007-2819-6

19. Arasimowicz-Jelonek M, Floryszak-Wieczorek J, Kosmala A (2011) Are nitric oxide donors a valuable tool to study the functional role of nitric oxide in plant metabolism. Plant Biol 13(5):747-756. https://doi.org/10.1111/j.1438-8677.2010.00430

20. Shi HT, Li RJ, Cai W, Liu W, Wang CL, Lu YT (2011) Increasing nitric oxide content in Arabidopsis thaliana by expressing rat neuronal nitric oxide synthase resulted in enhanced stress tolerance. Plant Cell Physiol 53(2):344-357. https://doi.org/10.1093/pcp/pcr181

21. Karuppusamy S (2009) A review on trends in production of secondary metabolites from higher plants by in vitro tissue, organ and cell cultures. J Med Plant Res 3(13):1222-1239

22. Szakiel A, Pączkowski C, Henry M (2011) Influence of environmental abiotic factors on the content of saponins in plants. Phytochemistry 10(4):471-491. https://doi.org/10.1007/s11101010-9177

23. Golkar P, Taghizadeh M (2018) In vitro evaluation of phenolic and osmolite compounds, ionic content and antioxidant activity in safflower (Carthamus tinctorius L.) under salinity stress. Plant Cell Tissue Org Cult 134(3):357-368. https://doi.org/10.1007/s11240-018-1427-4

24. Hodaei M, Rahimmalek M, Arzani A, Talebi M (2018) The effect of water stress on phytochemical accumulation, bioactive compounds and expression of key genes involved in flavonoid biosynthesis in Chrysanthemum morifolium L. Ind Crops Prod 120:295-304. https:// doi.org/10.1016/j.indcrop.2018

25. Winkel-Shirley B (2001) Flavonoid biosynthesis. A colorful model for genetics, biochemistry, cell biology and biotechnology. Plant Physiol 126(2):485-493. https://doi.org/10.1104/ pp.126.2.485 
26. Berli FJ, Moreno D, Piccoli P, Hespanhol-Viana L, Silva MF, Bressan-Smith R, Cavagnaro JB, Bottini R (2010) Abscisic acid is involved in the response of grape (Vitis vinifera $\mathrm{L}$.) cv. Malbec leaf tissues to ultraviolet-B radiation by enhancing ultraviolet-absorbing compounds, antioxidant enzymes and membrane sterols. Plant Cell Environ 33(1):1-10. https://doi.org/ 10.1111/j.1365-3040.2009.02044

27. Ramakrishna A, Ravishankar GA (2011) Influence of abiotic stress signals on secondary metabolites in plants. Plant Signal Behav 6(11):1720-1731. https://doi.org/10.4161/psb.6. 11.17613

28. Uleberg E, Rohloff J, Jaakola L, Trôst K, Junttila O, Häggman H, Martinussen I (2012) Effects of temperature and photoperiod on yield and chemical composition of northern and southern clones of bilberry (Vaccinium myrtillus L.). J Agric Food Chem 60(42):10406-10414. https:// doi.org/10.1021/jf302924m

29. Aziz A, Martin-Tanguy J, Larher F (1998) Stress-induced changes in polyamine and tyramine levels can regulate proline accumulation in tomato leaf discs treated with sodium chloride. Physiol Plant 104(2):195-202. https://doi.org/10.1034/j.1399-3054.1998.1040207

30. Jaafar HZ, Ibrahim MH, Fakri M, Farhana N (2012) Impact of soil field water capacity on secondary metabolites, phenylalanine ammonia-lyase (PAL), malondialdehyde (MDA) and photosynthetic responses of Malaysian Kacip Fatimah (Labisia pumila Benth). Molecules 17(6):7305-7322. https://doi.org/10.3390/molecules17067305

31. Nowak M, Kleinwächter M, Manderscheid R, Weigel HJ, Selmar D (2010) Drought stress increases the accumulation of monoterpenes in sage (Salvia officinalis), an effect that is compensated by elevated carbon dioxide concentration. J Appl Bot Food Qual 83(2):133-136

32. Afzal Shah F, Kareem YA, Habib UR, Ali BG (2017) Impact of drought stress on active secondary metabolite production in Cichorium intybus roots. J Appl Environ Biol Sci 7(7):39-43

33. Szabó B, Tyihák E, Szabó G, Botz L (2003) Mycotoxin and drought stress induced change of alkaloid content of Papaver somniferum plantlets. Acta Bot Hungar 45:409-417. https://doi. org/10.1556/ABot.45.2003

34. Chen Y, Guo Q, Liu L, Liao L, Zhu Z (2011) Influence of fertilization and drought stress on the growth and production of secondary metabolites in Prunella vulgaris L. J Med Plant Res 5(9):1749-1755. https://doi.org/10.1371/journal.pone.0066259

35. Singh S, Sinha S (2005) Accumulation of metals and its effects in Brassica juncea (L.) Czern. (cv. Rohini) grown on various amendments of tannery waste. Ecotoxicol Environ Saf 62(1):118-127. https://doi.org/10.1016/j.ecoenv.2004.12.026

36. Umar S, Gauba N, Anjum NA, Siddiqi TO (2013) Arsenic toxicity in garden cress (Lepidium sativum Linn.): significance of potassium nutrition. Environ Sci Pollut Res Int 20(9): 6039-6049. https://doi.org/10.1007/s11356-013-1624-y

37. Sharma RK, Agrawal M, Agrawal SB (2010) Physiological, biochemical and growth responses of lady's finger (Abelmoschus esculentus L.) plants as affected by Cd contaminated soil. Bull Environ Contam Toxicol 84(6):765-770. https://doi.org/10.1007/s00128010-0032-y

38. Helmig D, Ortega J, Duhl T, Tanner D, Guenther A, Harley P, ... Sakulyanontvittaya T (2007) Sesquiterpene emissions from pine trees - identifications, emission rates and flux estimates for the contiguous United States. Environ Sci Technol 41 (5):1545-1553. https://doi.org/10.1021/ es0618907

39. Hanson DT, Sharkey TD (2001) Effect of growth conditions on isoprene emission and other thermotolerance-enhancing compounds. Plant Cell Environ 24:929-936. https://doi.org/ 10.1046/j.1365-3040.2001.00744

40. Mølmann JA, Steindal AL, Bengtsson GB, Seljåsen R, Lea P, Skaret J, Johansen TJ (2015) Effects of temperature and photoperiod on sensory quality and contents of glucosinolates, flavonols and vitamin C in broccoli florets. Food Chem 172:47-55. https://doi.org/10.1016/j. foodchem.2014.09.015 
41. Zu YG, Tang ZH, Yu JH, Liu SG, Wang W, Guo XR (2003) Different responses of camptothecin and 10-hydroxycamptothecin to heat shock in Camptotheca acuminata seedlings. Acta Bot Sin 45:809-814. http://hdl.handle.net/1807/1704

42. Morison JIL, Lawlor DW (1999) Interactions between increasing $\mathrm{CO}_{2}$ concentration and temperature on plant growth. Plant Cell Environ 22(6):659-682. https://doi.org/10.1046/ j.1365-3040.1999.00443

43. Bernáth J, Tétényi P (1979) The effect of environmental factors on growth. Development and alkaloid production of poppy (Papaver somniferum L.): I. Responses to day-length and light intensity. Biochem Physiol Pflanz 174:468-478

44. Dutta A, Sen J, Deswal R (2007) Downregulation of terpenoid indole alkaloid biosynthetic pathway by low temperature and cloning of a AP2 type C-repeat binding factor (CBF) from Catharanthus roseus (L). G. Don. Plant Cell Rep 26(10):1869-1878. https://doi.org/10.1007/ s00299-007-0383-y

45. Hummel I, El Amrani A, Gouesbet G, Hennion F, Couée I (2004) Involvement of polyamines in the interacting effects of low temperature and mineral supply on Pringlea antiscorbutica (Kerguelen cabbage) seedlings. J Exp Bot 55:1125-1134. https://doi.org/10.1093/jxb/erh126

46. Havkin-Frenkel D, Podstolski A, Knorr D (1996) Effect of light on vanillin precursors formation by in vitro cultures of Vanilla planifolia. Plant Cell Tissue Org Cult 45(2): 133-136. https://doi.org/10.1051/fruits:2006015

47. Anasori P, Asghari G (2008) Effects of light and differentiation on gingerol and zingiberene production in cultured cells of Zingiber officinale. Planta Med 3(1):59-63. https://doi.org/ $10.1055 / \mathrm{s}-0029-1234839$

48. Kliewer WM (1977) Influence of temperature, solar radiation and nitrogen on coloration and composition of Emperor grapes. Am J Enol Vitic 28(2):96-103

49. Carvalho IS, Cavaco T, Carvalho LM, Duque P (2010) Effect of photoperiod on flavonoid pathway activity in sweet potato (Ipomoea batatas (L.) Lam.) leaves. Food Chem 118:384-390. https://doi.org/10.1016/j.foodchem.2009.05.005

50. Antognoni F, Zheng S, Pagnucco C, Baraldi R, Poli F, Biondi S (2007) Induction of flavonoid production by UV-B radiation in Passiflora quadrangularis callus cultures. Fitoterapia 78(5): 345-352. https://doi.org/10.1016/j.fitote.2007.02.001

51. Regvar M, Bukovnik U, Likar M, Kreft I (2012) UV-B radiation affects flavonoids and fungal colonisation in Fagopyrum esculentum and F. tataricum. Cent Eur J Biol 7(2):275-283. https://doi.org/10.2478/s11535-012-0017-4

52. Warren JM, Bassman JH, Fellman JK, Mattinson DS, Eigenbrode S (2003) Ultraviolet-B radiation alters phenolic salicylate and flavonoid composition of Populus trichocarpa leaves. Tree Physiol 23(8):527-535

53. Janská A, Maršík P, Zelenková S, Ovesná J (2010) Cold stress and acclimation-what is important for metabolic adjustment? Plant Biol 12(3):395-405. https://doi.org/10.1111/ j.1438-8677.2009.00299.x

54. Wu GJ, Chen TG, Chang HC, Chiu WT, Chang CC, Chen RM (2007) Nitric oxide from both exogenous and endogenous sources activates mitochondria-dependent events and induces insults to human chondrocytes. J Cell Biochem 101(6):1520-1531. https://doi.org/10.1002/ jcb. 21268

55. Janas KM, Cvikrová M, Pałagiewicz A, Szafranska K, Posmyk MM (2002) Constitutive elevated accumulation of phenylpropanoids in soybean roots at low temperature. Plant Sci 163(2):369-373. https://doi.org/10.1016/S0168-9452(02)00136-X

56. Yang L, Wen KS, Ruan X, Zhao YX, Wei F, Wang Q (2018) Response of plant secondary metabolites to environmental factors. Molecules 23(4):762. https://doi.org/10.3390/molecules 23040762

57. Neffati M, Sriti J, Hamdaoui G, Kchouk ME, Marzouk B (2011) Salinity impact on fruit yield, essential oil composition and antioxidant activities of Coriandrum sativum fruit extracts. Food Chem 124(1):221-225. https://doi.org/10.1016/j.foodchem.2010.06.022 
58. Fatima S, Mujib A, Tonk D (2015) $\mathrm{NaCl}$ amendment improves vinblastine and vincristine synthesis in Catharanthusroseus: a case of stress signalling as evidenced by antioxidant enzymes activities. Plant Cell Tissue Org Cult 121(2):445-458. https://doi.org/10.1007/ s11240-015-0715-5

59. Vaughan MM, Christensen S, Schmelz EA, Huffaker A, Mcauslane HJ, Alborn HT, ... Teal PE (2015) Accumulation of terpenoid phytoalexins in maize roots is associated with drought tolerance. Plant Cell Environ 38(11):2195-2207. https://doi.org/10.1111/pce.12482. Epub 2015 Jan 23

60. Warren CR, Aranda I, Cano FJ (2012) Metabolomics demonstrates divergent responses of two Eucalyptus species to water stress. Metabolomics 8(2):186-200. https://doi.org/10.1007/ s11306-011-0299-y

61. Jaleel CA, Manivannan P, Sankar B, Kishorekumar A, Gopi R, Somasundaram R, Panneerselvam R (2007) Induction of drought stress tolerance by ketoconazole in Catharanthus roseus is mediated by enhanced antioxidant potentials and secondary metabolite accumulation. Colloids Surf B Biointerfaces 60(2):201-206. https://doi.org/10.1016/j. colsurfb.2007.06.010

62. Shohael AM, Ali MB, Yu KW, Hahn EJ (2005) Effect of temperature on secondary metabolite production and antioxidant enzyme activities in Eleutherococcus senticosus somatic embryos. Plant Cell Tissue Org Cult 85(2):219-228

63. Trejo-Tapia G, Jimenez-Aparicio A, Rodriguez-Monroy M, De Jesus-Sanchez A, GutierrezLopez G (2001) Influence of cobalt and other microelements on the production of betalains and the growth of suspension cultures of Beta vulgaris. Plant Cell Tissue Org Cult 67(1): 19-23. https://doi.org/10.1023/A:1011684619614

64. Zheng Z, Wu M (2004) Cadmium treatment enhances the production of alkaloid secondary metabolites in Catharanthus roseus. Plant Sci 166(2):507-514. https://doi.org/10.1016/j. plantsci.2003.10.022

65. Pitta-Alvarez SI, Spollansky TC, Giulietti AM (2000) The influence of different biotic and abiotic elicitors on the production and profile of tropane alkaloids in hairy root cultures of Brugmansia candida. Enzyme Microb Technol 26(2-4):252-258

66. Maksymiec W, Wianowska D, Dawidowicz AL, Radkiewicz S, Mardarowicz M, Krupa Z (2005) The level of jasmonic acid in Arabidopsis thaliana and Phaseolus coccineus plants under heavy metal stress. J Plant Physiol 162(12):1338-1346. https://doi.org/10.1016/j. jplph.2005.01.013

67. Rakwal R, Tamogami S, Kodama O (1996) Role of jasmonic acid as a signaling molecule in copper chloride-elicited rice phytoalexin production. Biosci Biotechnol Biochem 60(6): 1046-1048. https://doi.org/10.1271/bbb.60.1046

68. Neill S, Barros R, Bright J, Desikan R, Hancock J, Harrison J, . . Wilson I (2008) Nitric oxide, stomatal closure, and abiotic stress. J Exp Bot 9(2):165-176. https://doi.org/10.1093/jxb/ erm293

69. García-Mata C, Lamattina L (2001) Nitric oxide induces stomatal closure and enhances the adaptive plant responses against drought stress. Plant Physiol 126(3):1196-1204

70. Planchet E, Verdu I, Delahaie J, Cukier C, Girard C, Morère-Le Paven MC, Limami AM (2014) Abscisic acid-induced nitric oxide and proline accumulation in independent pathways under water-deficit stress during seedling establishment in Medicago truncatula. J Exp Bot 65(8):2161-2170. https://doi.org/10.1093/jxb/eru088

71. Liao WB, Huang GB, Yu JH, Zhang ML (2012) Nitric oxide and hydrogen peroxide alleviate drought stress in marigold explants and promote its adventitious root development. Plant Physiol Biochem 58:6-15. https://doi.org/10.1016/j.plaphy.2012.06.012

72. Farooq M, Wahid A, Kobayashi N, Fujita D, Basra SMA (2009) Plant drought stress: effects, mechanisms and management. Agron Sustain Dev 29:185-212. https://doi.org/10.1051/ agro:2008021

73. Fan H, Guo S, Jiao Y, Zhang R, Li J (2007) Effects of exogenous nitric oxide on growth, active oxygen species metabolism, and photosynthetic characteristics in cucumber seedlings under $\mathrm{NaCl}$ stress. Front Agric 1(3):308-314. https://doi.org/10.1007/s11703-007-0052-5 
74. Uchida A, Jagendorf A, Hibino T, Takabe T (2002) Effects of hydrogen peroxide and nitric oxide on both salt and heat stress tolerance in rice. Plant Sci 163:515-523. https://doi.org/ 10.1016/S0168-9452(02)00159-0

75. Fatima M, Masood A, Per TS, Khan NA (2016) Nitric oxide alleviates salt stress inhibited photosynthetic performance by interacting with sulfur assimilation in mustard. Front Plant Sci 7:521. https://doi.org/10.3389/fpls.2016.00521

76. Egbichi I, Keyster M, Ludidi N (2014) Effect of exogenous application of nitric oxide on salt stress responses of soybean. S Afr J Bot 90:131-136. https://doi.org/10.1016/j.sajb. 2013.11.002

77. Dong YJ, Jinc SS, Liu S, Xu LL, Kong J (2014) Effects of exogenous nitric oxide on growth of cotton seedlings under $\mathrm{NaCl}$ stress. J Soil Sci Plant Nutr 14(1). https://doi.org/10.4067/S071895162014005000001

78. Liu X, Liu B, Xue S, Cai Y, Qi W, Jian C, ... Ren H (2016) Cucumber (Cucumis sativus L.) nitric oxide synthase associated gene1 (CsNOA1) plays a role in chilling stress. Front Plant Sci 11(7):1652. https://doi.org/10.3389/fpls.2016.01652

79. Chaki M, Valderrama R, Fernández-Ocaña AM, Carreras A, Gómez-Rodríguez MV, LópezJaramillo JVIER, ... Corpas FJ (2011) High temperature triggers the metabolism of $S$-nitrosothiols in sunflower mediating a process of nitrosative stress which provokes the inhibition of ferredoxin-NADP reductase by tyrosine nitration. Plant Cell Environ 34(11): 1803-1818. https://doi.org/10.1111/j.1365-3040.2011.02376.x

80. Airaki M, Leterrier M, Mateos RM, Valderrama R, Chaki M, Barroso JB, . . Corpas FJ (2012) Metabolism of reactive oxygen species and reactive nitrogen species in pepper (Capsicum annuum L.) plants under low temperature stress. Plant Cell Environ 35(2):281-295. https:// doi.org/10.1111/j.1365-3040.2011.02310.x

81. Ashraf MFMR, Foolad M (2007) Roles of glycine betaine and proline in improving plant abiotic stress resistance. Environ Exp Bot 59:206-216. https://doi.org/10.1016/j.envexpbot. 2005.12.006

82. Ziogas V, Tanou G, Filippou P, Diamantidis G, Vasilakakis M, Fotopoulos V, Molassiotis A (2013) Nitrosative responses in citrus plants exposed to six abiotic stress conditions. Plant Physiol Biochem 68:118-126. https://doi.org/10.1016/j.plaphy.2013.04.004

83. Chen K, Chen L, Fan J, Fu J (2013) Alleviation of heat damage to photosystem II by nitric oxide in tall fescue. Plant Physiol Biochem 68:118-126. https://doi.org/10.1016/j.plaphy. 2013.04.004

84. Hasanuzzaman M, Fujita M (2013) Exogenous sodium nitroprusside alleviates arsenicinduced oxidative stress in wheat (Triticum aestivum L.) seedlings by enhancing antioxidant defense and glyoxalase system. Ecotoxicology 22(3):584-596. https://doi.org/10.1007/ s10646-013-1050-4

85. Kopyra M, Stachon-Wilk M, Gwozez EA (2006) Effect of exogenous nitric oxide on the anti oxidant capacity of cadmium-treated soybean cell suspension. Acta Physiol Plant 28:525-536. https://doi.org/10.1007/s11738-006-0048-4

86. Cerana R, Malerba M (2015) Role of nitric oxide in heavy metal stress. Springer, Cham, pp 181-192. https://doi.org/10.1007/978-3-319-17804-2_12

87. Sun C, Lu L, Liu L, Liu W, Yu Y, Liu X, Hu Y, Jin C, Lin X (2014) Nitrate reductase-mediated early nitric oxide burst alleviates oxidative damage induced by aluminum through enhancement of antioxidant defenses in roots of wheat (Triticum aestivum). New Phytol 201(4): 1240-1250. https://doi.org/10.1111/nph.12597

88. Ahlfors R, Brosché M, Kollist H, Kangasjärvi J (2009) Nitric oxide modulates ozone-induced cell death, hormone biosynthesis and gene expression in Arabidopsis thaliana. Plant $\mathrm{J}$ 58(1):1-12. https://doi.org/10.1111/j.1365-313X.2008.03756.x

89. Vanzo E, Ghirardo A, Merl-Pham J, Lindermayr C, Heller W, Hauck SM, ... Schnitzler JP (2014) $S$-nitroso-proteome in poplar leaves in response to acute ozone stress. PLoS One 9(9): e106886. https://doi.org/10.1371/journal.pone.0106886

90. Zhang M, Dong JF, Jin HH, Sun LN, Xu MJ (2011) Ultraviolet-B-induced flavonoid accumulation in Betula pendula leaves is dependent upon nitrate reductase-mediated nitric oxide signaling. Tree Physiol 31(8):798-807. https://doi.org/10.1093/treephys/tpr070 
91. Krasylenko YA, Yemets AI, Sheremet YA, Blume YB (2012) Nitric oxide as a critical factor for perception of UV-B irradiation by microtubules in Arabidopsis. Physiol Plant 145(4): 505-515. https://doi.org/10.1111/j.1399-3054.2011.01530.x

92. Tossi V, Lombardo C, Cassia R, Lamattina L (2012) Nitric oxide and flavonoids are systemically induced by UV-B in maize leaves. Plant Sci 103:193-194. https://doi.org/10.1016/j. plantsci.2012.05.012

93. Cui JX, Zhou YH, Ding JG, Xia XJ, Shi KAI, Chen SC, ... Yu JQ (2011) Role of nitric oxide in hydrogen peroxide-dependent induction of abiotic stress tolerance by brassinosteroids in cucumber. Plant Cell Environ 34(2):347-358. https://doi.org/10.1111/j.1365-3040.2010. 02248.x

94. Xu MJ (2007) Nitric oxide: a potential key point of the signaling network leading to plant secondary metabolite biosynthesis. Prog Nat Sci 17(12):1397-1404

95. Zhang B, Zheng LP, Wang JW (2012) Nitric oxide elicitation for secondary metabolite production in cultured plant cells. Appl Microbiol Biotechnol 93(2):455-466. https://doi. org $/ 10.1007 / \mathrm{s} 00253-011-3658-8$

96. Xu M, Dong J (2005) Elicitor-induced nitric oxide burst is essential for triggering catharanthine synthesis in Catharanthus roseus suspension cells. Appl Microbiol Biotechnol 67(1):40-44. https://doi.org/10.1007/s00253-004-1737-9

97. ZhangJ XM (2006) Effects of nitric oxide and methyljasmonate on the baicalin production and cell growth in suspension cultures of Scutellaria baicalensis. Chin Sci Bull 23:374-379

98. Liao W, Xiao H, Zhang M (2009) Role and relationship of nitric oxide and hydrogen peroxide in adventitious root development of marigold. Acta Physiol Plant 31(6):1279-1289. https:// doi.org/10.1007/s11738-009-0367-3

99. Xu MJ, Dong JF (2008) Synergistic action between jasmonic acid and nitric oxide in inducing matrine accumulation of Sophora flavescens suspension cells. J Integr Plant Biol 50(1): 92-101. https://doi.org/10.1111/j.1744-7909.2007.00570.x

100. Wu SJ, Qi JL, Zhang WJ, Liu SH, Xiao FH, Zhang MS, ... Shen HG (2008) Nitric oxide regulates shikonin formation in suspension-cultured Onosma paniculatum cells. Plant Cell Physiol 50(1):118-128. https://doi.org/10.1093/pcp/pcn178

101. Ai J, Zhou B, Jia J (2009) The effects of $\mathrm{NO}$ and $\mathrm{AgNO}_{3}$ on cell growth and salidroside synthesis in Rhodiola sachalinensis A. Bor. cell suspension culture. J Microbial Biochem Technol 1(1):11-14

102. Zheng LP, Guo YT, Wang JW, Tan RX (2008) Nitric oxide potentiates oligosaccharideinduced artemisinin production in Artemisia аппиа hairy roots. J Integr Plant Biol 50(1): 49-55. https://doi.org/10.1111/j.1744-7909.2007.00589.x

103. Wang Y, Dai C, Zhao Y, Peng Y (2011) Fungal endophyte-induced volatile oil accumulation in Atractylodes lancea plantlets is mediated by nitric oxide, salicylic acid and hydrogen peroxide. Process Biochem 46(3):730-735. https://doi.org/10.1016/j.procbio.2010.11.020

104. Fang F, Dai C, Wang Y (2009) Role of nitric oxide and hydrogen peroxide in the essential oil increasing of suspension cells from Atractylodes lancea induced by endophytic fungal Cunninghamella sp. AL4 elicitor. Sheng Wu Gong Cheng Xue Bao 25(10):1490-1496

105. Xu MJ, Dong JF, Zhu MY (2005) Nitric oxide mediates the fungal elicitor-induced hypericin production of Hypericum perforatum cell suspension cultures through a jasmonic-acid-dependent signal pathway. Plant Physiol 139(2):991-998. https://doi.org/10.1104/pp.105.066407

106. Hao G, Du X, Zhao F, Shi R, Wang J (2009) Role of nitric oxide in UV-B-induced activation of PAL and stimulation of flavonoid biosynthesis in Ginkgo biloba callus. Plant Cell Tissue Org Cult 97(2):175-185. https://doi.org/10.1007/s11240-009-9513-2

107. Qu Y, Feng H, Wang Y, Zhang M, Cheng J, Wang X, An L (2006) Nitric oxide functions as a signal in ultraviolet-B induced inhibition of pea stems elongation. Plant Sci 170(5):994-1000. https://doi.org/10.1016/j.plantsci.2006.01.003

108. Li DW, Li ML, Liu Y, Zu YG (2015) Effect of nitric oxide on the secondary metabolites of Taxus chinensis var. mairei under UV-B exposure. Adv Mater Res 1073:114-117. Trans Tech Publications. https://doi.org/10.4028/www.scientific.net/AMR.1073-1076.114 
109. Gharibi S, Tabatabaei BES, Saeidi G, Goli SAH (2016) Effect of drought stress on total phenolic, lipid peroxidation, and antioxidant activity of Achillea species. Appl Biochem Biotechnol 178(4):796-809. https://doi.org/10.1007/s12010-015-1909-3

110. Hao GP, Du XH, Hai RJ (2007) Exogenous nitric oxide accelerates soluble sugar, proline and secondary metabolite synthesis in Ginkgo biloba under drought stress. J Plant Physiol Mol Biol 33:499-506

111. Krol A, Amarowicz R, Weidner S (2014) Changes in the composition of phenolic compounds and antioxidant properties of grapevine roots and leaves (Vitis vinifera L.) under continuous of long-term drought stress. Acta Physiol Plant 36(6):1491-1499. https://doi.org/10.1007/ s11738-014-1526-8

112. Du ST, Liu Y, Zhang P, Liu HJ, Zhang XQ, Zhang RR (2015) Atmospheric application of trace amounts of nitric oxide enhances tolerance to salt stress and improves nutritional quality in spinach (Spinacia oleracea L.). Food Chem 173:905-911

113. Hassan ALM, Fuertes MM, Sánchez FJR, Vicente O, Boscaiu M (2015) Effects of salt and water stress on plant growth and on accumulation of osmolytes and antioxidant compounds in cherry tomato. Not Bot Horti Agrobot Cluj-Napoca 43(1):1-11. https://doi.org/10.15835/ nbha4319793

114. Mohamed HI, Latif HH, Hanafy RS (2016) Influence of nitric oxide application on some biochemical aspects, endogenous hormones, minerals and phenolic compounds of Vicia faba plant grown under arsenic stress. Gesunde Pflanz 68(2):99-107. https://doi.org/10.1007/ s10343-016-0363-7

115. Zhang LP, Mehta SK, Liu ZP, Yang ZM (2008) Copper-induced proline synthesis is associated with nitric oxide generation in Chlamydomonas reinhardtii. Plant Cell Physiol 49(3):411-419. https://doi.org/10.1093/pcp/pcn017

116. Gupta SK, Mandal P (2016) Assessment of the effect of nitric oxide and calcium ion on the therapeutic potential and oxidative stress status of fenugreek sprouts. Asian J Pharm Clin Res 9(2):271-277

117. Barman K, Siddiqui MW, Patel VB, Prasad M (2014) Nitric oxide reduces pericarp browning and preserves bioactive antioxidants in litchi. Sci Hortic 171:71-77. https://doi.org/10.1016/j. scienta.2014.03.036

118. El-Beltagi HS, Ahmed OK, Hegazy AE (2015) Molecular role of nitric oxide in secondary products production in Ginkgo biloba cell suspension culture. Not Bot Horti Agrobot Cluj-Napoca 43(1):12-18

119. Wang JW, Zheng LP, Zhang B, Zou T (2009) Stimulation of artemisinin synthesis by combined cerebroside and nitric oxide elicitation in Artemisia annua hairy roots. Appl Microbiol Biotechnol 85(2):285-292. https://doi.org/10.1007/s00253-009-2090-9

120. Wang JW, Wu JY (2005) Nitric oxide is involved in methyl jasmonate-induced defense responses and secondary metabolism activities of Taxus cells. Plant Cell Physiol 46(6): 923-930. https://doi.org/10.1093/pcp/pci098

121. Hu X, Neill SJ, Cai W, Tang Z (2003) Nitric oxide mediates elicitor-induced saponin synthesis in cell cultures of Panax ginseng. Funct Plant Biol 30(8):901-907. https://doi.org/10.1071/ FP03061

122. Sarropoulou V, Maloupa E (2017) Effect of the NO donor "sodium nitroprusside" (SNP), the ethylene inhibitor "cobalt chloride" $\left(\mathrm{CoCl}_{2}\right)$ and the antioxidant vitamin E " $\alpha$-tocopherol" on in vitro shoot proliferation of Sideritis raeseri Boiss. \& Heldr. subsp. raeseri. Plant Cell Tissue Org Cult 128(3):619-629. https://doi.org/10.1007/s11240-016-1139-6

123. Foissner I, Wendehenne D, Langebartels C, Durner J (2000) In vivo imaging of an elicitorinduced nitric oxide burst in tobacco. Plant J 23(6):817-824. https://doi.org/10.1046/j.1365313X.2000.00835.X

124. Pružinská A, Tanner G, Aubry S, Anders I, Moser S, Müller T, ... Hörtensteiner S (2005) Chlorophyll breakdown in senescent Arabidopsis leaves. Characterization of chlorophyll catabolites and of chlorophyll catabolic enzymes involved in the degreening reaction. Plant Physiol 139(1):52-63. https://doi.org/10.1104/pp.105.065870

125. Durner J, Wendehenne D, Klessig DF (1998) Defense gene induction in tobacco by nitric oxide, cyclic GMP, and cyclic ADP-ribose. Proc Natl Acad Sci 95(17):10328-10333 
126. Zhao J, Fujita K, Sakai K (2007) Reactive oxygen species, nitric oxide, and their interactions play different roles in Cupressus lusitanica cell death and phytoalexin biosynthesis. New Phytol 175(2):215-229. https://doi.org/10.1111/j.1469-8137.2007.02109.x

127. Liang ZS, Yang DF, Liang X, Zhang YJ, Liu Y, Liu FH (2012) Roles of reactive oxygen species in methyl jasmonate and nitric oxide-induced tanshinone production in Salvia miltiorrhiza hairy roots. Plant Cell Rep 5:873-883. https://doi.org/10.1007/s00299-0111208-6

128. Arfan M, Zhang DW, Zou LJ, Luo SS, Tan WR, Zhu T, Lin HH (2019) Hydrogen peroxide and nitric oxide crosstalk mediates brassinosteroids induced cold stress tolerance in Medicago truncatula. Int J Mol Sci 20(1):144. https://doi.org/10.3390/ijms20010144 